\title{
下面増厚したRC床版のせん断補強効果 と疲労耐久性の評価に関する実験的研究
}

\author{
横山 和昭 1 佐藤 貢一 2 日野 伸一 3 \\ 1正会員 西日本高速道路株式会社 中国支社管理事業部（ ₹731-0103 広島市安佐南区緑井2-26-1） \\ (元 日本道路公団試験研究所道路研究部橋梁研究室) \\ E-mail: k.yokoyama.ac@w-nexco.co.jp \\ 2正会員 奈良建設株式会社 土木部技術課（ \\ E-mail: ko.satoh@nara-const.co.jp \\ 3フェロー会員 九州大学大学院教授 工学研究院建設デザイン部門（†819-0395 福岡市西区元岡744） \\ E-mail: hino@doc.kyushu-u.ac.jp
}

\begin{abstract}
道路橋RC床版の補強工法の一つである下面増厚工法は, 主に曲げに対してRC床版を補強するものであ り, せん断補強効果や疲労耐久性に関する効果は明確になっていない. 本研究では下面増厚工法の補強効 果を定量的に評価する目的で, 道路橋RC床版の最終的な破壞形態である押抜きせん断疲労破壞を考慮し, 梁状化した床版をモデル化したRC梁の定点載荷試験を実施した。さらに, 実物大規模のRC床版を下面増 厚補強した試験体を用いた輪荷重走行試験を実施した。実験の結果，RC梁供試体を用いた疲労試験は， 輪荷重走行試験と同様に下面増厚工法の補強効果を評価する上で有効であることを検証した。また，下面 増厚により補強されたRC床版の耐荷力や疲労耐久性に関する補強効果を検証した。
\end{abstract}

Key Words : RC slabs, bottom thickness increasing, shear strength, fatigue durability, S-N curve

\section{1. はじめに}

昭和 48 年以前の基準で設計された道路橋鉄筋コンク リート床版（以下， RC 床版と記す）は，現行の基準で 設計されたものに比べて，主桁間隔が広く，床版厚が薄 く, 配力鉄筋が少ない構造となっているため, 車両の繰 返し載荷に伴う疲労損傷が顕著である。 また，平成 5 年 11 月の車両制限令の改訂による通行車両の大型化に伴 い, 特に, 輪荷重を直接支持寸る $\mathrm{RC}$ 床版の劣化は加速 していくものと考えられる.

$\mathrm{RC}$ 床版の補強工法としては, 日本道路公団（以下， JH と記す）を主体として上面増厚工法に関する研究が なされ，現在では上面増厚工法が一般的な工法として採 用されているが，交通規制が不可能である等の理由で上 面からの施工が困難な場合には，下面からの補強が必要 とされている.

下面増厚工法は，図-1 に示すように，既設床版コン クリートの下面に鉄筋等の補強材を設置し，接着性に優 れたセメント系材料で増厚することにより，主に曲げに 対して床版を補強する工法であり，本工法の曲げ補強効 果に関しては多くの研究成果が報告されている.
一方，既往の研究により，下面増厚補強の対象となる ような既設道路橋床版は輪荷重の繰返し載荷に伴って橋 軸直角方向のひび割れが発生した後に梁状化し，最終的 には押抜きせん断破壊することが明らかになっている. また, 床版の疲労耐久性の性能評価試験方法としては, 輪荷重走行試験機を用いた試験方法が提案されている1). このため，押抜きせん断に対する下面増厚工法の補強効 果についても，実物大相当の床版試験体により輪荷重走 行試験を実施して検証するのが望ましい.

そこで, 本研究では, セメント系の増厚材料の選定お よび補強鉄筋の径やかぶり厚等の増厚構造に関する検討 として，まず，梁状化した床版を模擬したRC梁に下面 増厚補強を施し, 定点載荷試験を実施した。次に, 実物 大相当のRC床版に下面増厚補強を施し, 輪荷重走行試 験を実施した。これらの実験結果より，下面増厚補強さ れたRC床版のせん断耐荷力や疲労耐久性に対寸る補強 効果について検証した。 さらに，RC梁を用いた定点載 荷試験とRC床版を用いた輪荷重走行試験の両者の試験 結果について, 疲労耐久性の評価の観点から考察するこ とにより， RC床版の下面増厚工法の疲労耐久性に関す る実用的な性能評価手法の提案を試みた。 


\section{RC梁の定点載荷試験}

\section{(1) 試験体の諸元}

$\mathrm{RC}$ 梁試験体は, 梁状化した道路橋 $\mathrm{RC}$ 床版を想定し て有効幅 ${ }^{2) を}$ を決定し，せん断破壊が先行寸るように設計 した上で ${ }^{3)}$ ，支間長および鉄筋量を設定し，図-2に示寸 ように支点部にハンチを設けた形状とした。

$\mathrm{RC}$ 梁の断面は，図-3 に示寸ように鉄筋（既設部： D16，増厚部：D10 もしくは D6）を配置し，表-1に示す セメント系材料で増厚して試験体を製作した.

下面増厚工法の施工実績では，増厚部の総厚を $22 \mathrm{~mm}$ とする構造が多い。この場合，直径 $6 \mathrm{~mm} の$ 補強鉄筋を格 子状に配置する際に，既設床版下面との間には隙間を設 けていない，その上で，純かぶりを $10 \mathrm{~mm}$ (表-1中のSG， FGの試験体）としている. しかし，今回の増厚 $50 \mathrm{~mm}$ と 寸る試験体では，補強鉄筋背面一の下面増厚材料の充填 性に配慮して，図-4に示寸ように補強鉄筋背面に $10 \mathrm{~mm}$
の隙間を設ける構造を主体とした．また，最適な増厚構 造に関する解析的研究出を参考にして，補強鉄筋は比較 的太径のD10鉄筋，純かぶりは $20 \mathrm{~mm} ，$ 増厚部の総厚は 50mmを主体とした。なお，図-3においては，D10の補強 鉄筋を4本配置した厚さ50mmの増厚構造を例示している が，厚さ22mmの増厚構造（ $\mathrm{SG}, \mathrm{FG}$ ）においては，厚さ $50 \mathrm{~mm}$ の増厚構造の補強鉄筋量と等しくする目的でD6の 補強鉄筋を9本配置した。

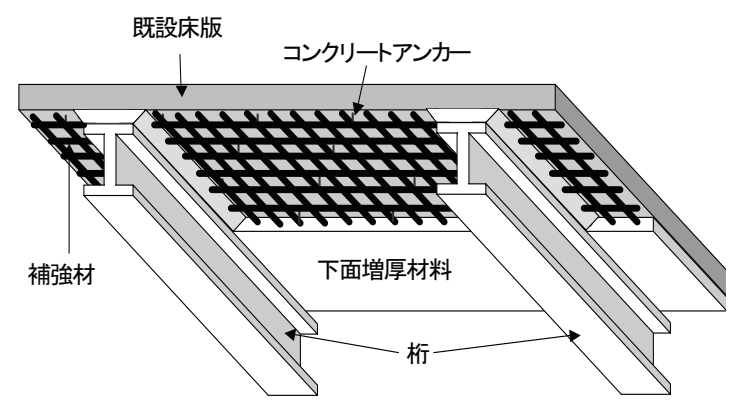

図-1 下面増厚工法の概念図

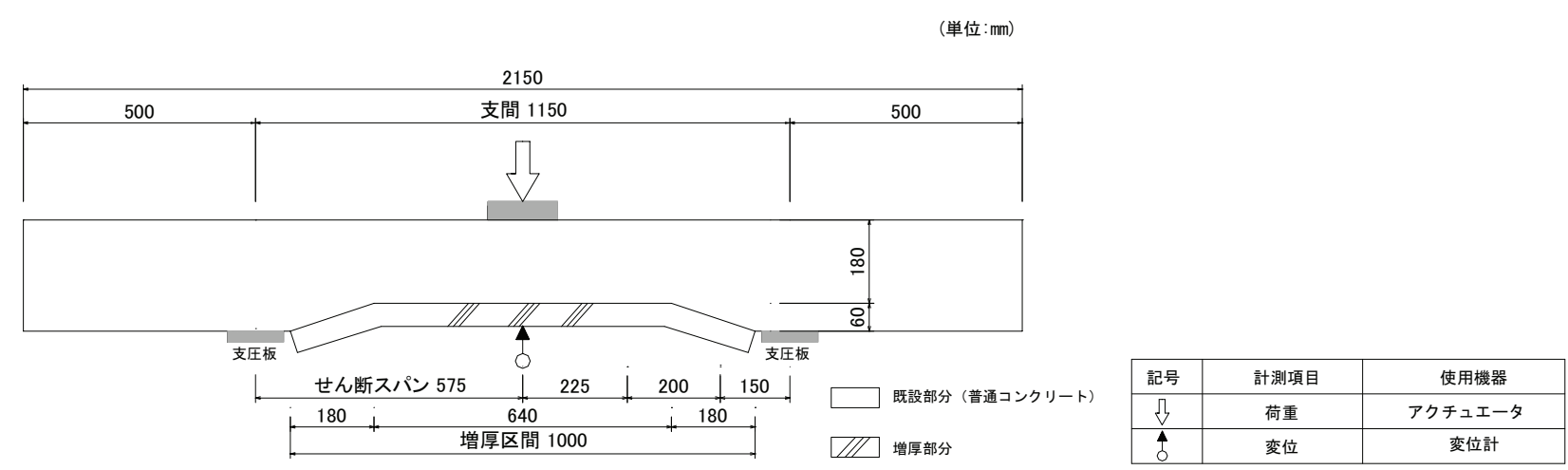

図-2 試験体の形状と計測位置

表-1 RC 梁試験体の概要

\begin{tabular}{|c|c|c|c|c|c|}
\hline \multicolumn{2}{|c|}{ 試験体の種別 } & \multirow[b]{2}{*}{$\begin{array}{c}\text { 下面増厚部のセメント系材料 } \\
\text { (補修用モルタル) }\end{array}$} & \multirow[b]{2}{*}{$\begin{array}{l}\text { 増厚部厚さ } \\
(\mathrm{mm})\end{array}$} & \multirow[b]{2}{*}{$\begin{array}{l}\text { 補強鉄筋径 } \\
(\mathrm{mm})\end{array}$} & \multirow[b]{2}{*}{ 表面処理工法 } \\
\hline $\begin{array}{l}\text { 静的 } \\
\text { 試験 }\end{array}$ & $\begin{array}{l}\text { 疲労 } \\
\text { 試験 }\end{array}$ & & & & \\
\hline SA & FA & " なし (無補強) & - & - & - \\
\hline SB & FB & ポリマーセメントモルタル A & 50 & 10 & WJ工法 \\
\hline $\mathrm{SC}$ & FC & ビニロン繊維混入セメントモルタル & 50 & 10 & WJ工法 \\
\hline SD & FD & 鋼繊維混入超速硬セメントモルタル & 50 & 10 & WJ工法 \\
\hline SE & FE & ポリマーセメントモルタル B & 50 & 10 & ブラスト工法 \\
\hline SF & FF & ポリマーセメントモルタル A & 50 & 10 & ブラスト工法 \\
\hline SG & FG & ポリマーセメントモルタル A & 22 & 6 & ブラスト工法 \\
\hline
\end{tabular}

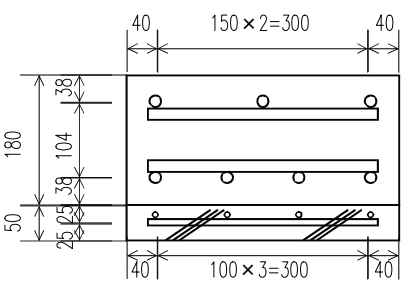

図-3 断面図

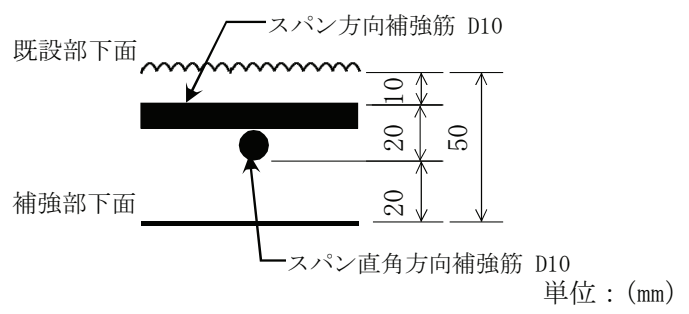

図-4 増厚部の構造 


\section{(2) 使用材料}

\section{a) 鉄筋}

試験体に使用した鉄筋は，せん断破壊に先行して曲げ 破壊が生じないように，表-2 に示寸引張強度を有する 高強度鉄筋とした。

\section{b) コンクリート}

$\mathrm{RC}$ 梁試験体のコンクリートは, 設計基準強度が $24 \mathrm{~N} / \mathrm{mm}^{2}$ の早強ポルトランドセメントを使用した。 載荷 試験実施時におけるコンクリートの強度試験結果を表-3 に示寸.

\section{c) 増厚部の使用材料}

増厚部は，表-1 に示すように事前に既設 RC 梁の下面 をウォータージェット(WJ)工法もしくはバキュームブラ スト工法で表面処理した．その後に，D10 または D6の 補強鉄筋を設置し，セメント系材料を用いて吹付け工法 により増厚した．増厚部に使用したセメント系材料は， ポリマーセメントモルタル A および B，ビニロン繊維 混入セメントモルタル, 鋼繊維混入超速硬セメントモル タルの 4 種類のモルタルを選定した. これらにより，既 設床版下面の表面処理工法および増厚材料の違いによる 補強効果の相違の比較を試みた. 増厚部モルタルの配合 を表-4に示し，増厚部モルタルの強度試験結果を表-5 に示す． SCおよび FCは，ビニロン䋊維混入のセメント モルタルのため, 引張強度が高くなった。

表-2 鉄筋の引張試験結果

\begin{tabular}{|c|c|c|c|}
\hline $\begin{array}{c}\text { 鉄筋 } \\
\text { 種類 }\end{array}$ & $\begin{array}{c}\text { 降伏点 } \\
\left(\mathrm{N} / \mathrm{mm}^{2}\right)\end{array}$ & $\begin{array}{c}\text { 引張強さ } \\
\left(\mathrm{N} / \mathrm{mm}^{2}\right)\end{array}$ & $\begin{array}{c}\text { 静弾性係数 } \\
\left(\times 10^{4} \mathrm{~N} / \mathrm{mm}^{2}\right)\end{array}$ \\
\hline D6 & - & 953 & 18.9 \\
\hline D10 & 790 & 984 & 21.1 \\
\hline D16 & 751 & 979 & 21.0 \\
\hline
\end{tabular}

表-3 コンクリートの強度試験結果

\begin{tabular}{|c|c|c|c|}
\hline 試験体 & $\begin{array}{c}\text { 圧縮強度 } \\
\left(\mathrm{N} / \mathrm{mm}^{2}\right)\end{array}$ & $\begin{array}{c}\text { 引張強度 } \\
\left(\mathrm{N} / \mathrm{mm}^{2}\right)\end{array}$ & $\begin{array}{c}\text { 静弾性係数 } \\
\left(\times 10^{4} \mathrm{~N} / \mathrm{mm}^{2}\right)\end{array}$ \\
\hline \hline $\mathrm{SA}, \mathrm{FA}$ & 33.6 & 2.81 & 2.77 \\
\hline $\mathrm{SB}, \mathrm{FB}$ & 35.8 & 2.95 & 2.76 \\
\hline $\mathrm{SC}, \mathrm{FC}$ & 37.7 & 2.53 & 2.75 \\
\hline $\mathrm{SD}, \mathrm{FD}$ & 38.1 & 2.53 & 2.75 \\
\hline $\mathrm{SE}, \mathrm{FE}$ & 36.9 & 3.09 & 2.55 \\
\hline $\mathrm{SF}, \mathrm{FF}$ & 37.7 & 3.26 & 2.52 \\
\hline $\mathrm{SG}, \mathrm{FG}$ & 38.7 & 3.23 & 2.59 \\
\hline
\end{tabular}

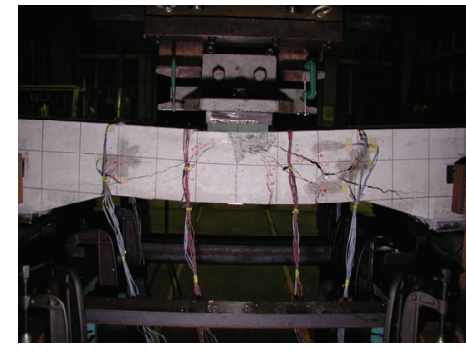

(a) 試験体 SA

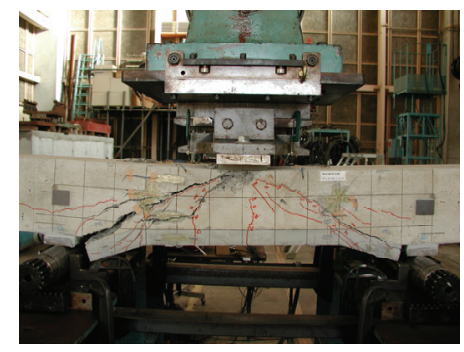

(b) 試験体 SB

\section{(3) 載荷方法}

\section{a) 静的載荷試験}

載荷試験は輪荷重を模擬して 1 点載荷を選定し，載荷 幅を $100 \mathrm{~mm}$ とし, 定点載荷により破壊荷重の計算值の 40\%から 80\%まで 10\%間隔で荷重制御により漸増させ る方法で実施した. なお, 載荷により非線形性が確認さ れた後は, 荷重制御から変位制御に変更して載荷した.

\section{b) 疲労試験}

疲労試験の最大荷重の設定は, 無補強試験体(SA)の静 的破壊荷重の実測値 $295 \mathrm{kN}$ の $40 \%$ である $118 \mathrm{kN}$ の荷重 を 100 万回まで載荷した．その後，各試験体の静的破壊 荷重の概齐 $50 \%$ に荷重を上げて疲労破壊するまで繰返 し載荷した。 なお, 最小荷重は $20 \mathrm{kN}$, 繰返し速度は 3Hzとした.

\section{(4) 静的載荷試験結果}

a) 静的破壊性状

最終的な破壊は7種類の試験体のいずれも写真-1に示 すような支点部からのせん断ひび割れによる破壊であり， ほぼ同様な経緯を経て破壊に至った。

表-4 増厚部モルタルの配合

\begin{tabular}{|c|c|c|c|c|c|}
\hline 増厚材料 & $\begin{array}{c}\text { セメント } \\
(\mathrm{kg})\end{array}$ & $\begin{array}{c}\text { ポリマー } \\
(\mathrm{kg})\end{array}$ & $\begin{array}{c}\begin{array}{c}\text { 細骨材 } \\
(\mathrm{kg})\end{array} \\
\end{array}$ & $\begin{array}{l}\text { 水 } \\
(\mathrm{kg})\end{array}$ & $\begin{array}{l}\text { W/C } \\
(\%) \\
\end{array}$ \\
\hline $\begin{array}{c}\text { ポリマーセメント } \\
\text { モルタルA }\end{array}$ & 872 & 96 & 1128 & 280 & 32.1 \\
\hline $\begin{array}{c}\text { ポリマーセメント } \\
\text { モルタル }\end{array}$ & 536 & 64 & 1472 & 224 & 42.1 \\
\hline $\begin{array}{l}\text { ビニロン繊維混入 } \\
\text { セメンル }\end{array}$ & 940 & 0 & 1060 & 430 & 45.7 \\
\hline $\begin{array}{l}\text { 鋼䋊維混入超速硬 } \\
\text { セメンモルタルト }\end{array}$ & 512 & 0 & 1536 & 230 & 45.0 \\
\hline
\end{tabular}

表-5 増厚部モルタルの強度試駼結果

\begin{tabular}{|c|c|c|c|c|}
\hline 試験体 & $\begin{array}{c}\text { 圧縮強度 } \\
\left(\mathrm{N} / \mathrm{mm}^{2}\right) \\
\end{array}$ & $\begin{array}{c}\text { 引張強度 } \\
\left(\mathrm{N} / \mathrm{mm}^{2}\right) \\
\end{array}$ & 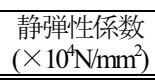 & 増厚材料 \\
\hline $\mathrm{SB}, \mathrm{FB}$ & 45.7 & 3.51 & 2.23 & $\begin{array}{c}\text { ポリマーセメント } \\
\text { モルタルA }\end{array}$ \\
\hline $\mathrm{SC}, \mathrm{FC}$ & 38.3 & 6.36 & 1.91 & $\begin{array}{l}\text { ビニロン緎維混入 } \\
\text { セメントモルル }\end{array}$ \\
\hline $\mathrm{SD}, \mathrm{FD}$ & 63.9 & 4.86 & 2.42 & $\begin{array}{l}\text { 鋼䋊維混入超速硬 } \\
\text { セメンモルタル }\end{array}$ \\
\hline SE,FE & 31.1 & 3.09 & 1.72 & $\begin{array}{l}\text { ポリマーセメント } \\
\text { モルタル } \mathrm{B}\end{array}$ \\
\hline $\mathrm{SF}, \mathrm{FF}$ & 35.4 & 3.38 & 1.67 & $\begin{array}{c}\text { ポリマーセメント } \\
\text { モルタル A }\end{array}$ \\
\hline SG,FG & 40.6 & 2.77 & 1.82 & $\begin{array}{c}\text { ポリマーセメント } \\
\text { モルタル A }\end{array}$ \\
\hline
\end{tabular}

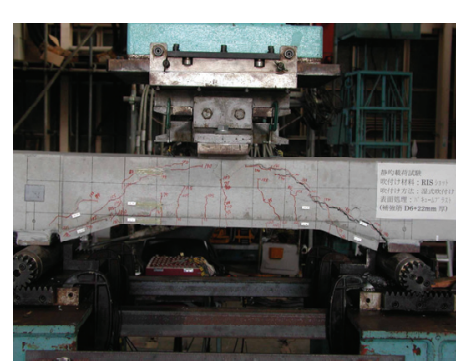

(c) 試験体 SG

写真-1 静的載荷試験体の破壊状況例 
曲げひび割れは，梁中央部の載荷点直下に発生し， その後，新たな曲げひび割れが，梁中央とハンチ上端 の中央付近に荷重の増加とともに発生した．曲げひび 割れはハンチ上端間に，50 mm増厚の供試体が3本， 22mm増厚の供試体が5本程度発生した。これは, 増厚 量が厚い50mm増厚の供試体の曲げ剛性が22 $\mathrm{mm}$ 増厚の 供試体と比較して高く, 22mm増厚の供試体はひび割れ が分散したのに対して，50mm増厚の供試体ではひび割 れが集中したことによるものと考えられる. その後, 荷重の増加とともに支点よりせん断ひび割れが発生し， 耐荷力の増加を示した後にせん断破壊に至った。 なお, $\mathrm{RC}$ 梁と増厚部分の界面の剥離は認められなかった。こ の破壊形態は損傷が進行し, 梁状化した後に押抜きせ 儿断破壊寸る道路橋RC床版の梁状化後の破壊形態を再 現できているものといえる.

曲げひび割れとせん断ひび割れの発生荷重および破 壊荷重を表-6 に示す。曲げひび割れの発生荷重は, 無 補強(SA) で $35 \mathrm{kN}$ ，補強後(SB〜SE)で $45 \sim 75 \mathrm{kN}$ であり, 無補強に比べて下面増厚補強後は 1.29〜2.14 倍に増加し た.この曲げひび割れ発生荷重の向上から曲げ補強効 果が確認できる，せん断ひび割れ発生荷重は，無補強 (SA)で $150 \mathrm{kN}$ ，補強後 $(\mathrm{SB} \sim \mathrm{SC})$ ) $155 \mathrm{kN} \sim 215 \mathrm{kN}$ で，無 補強に比べて下面増厚補強後は最大 1.43 倍まで増加し た. スターラップを有しない増厚後の $\mathrm{RC}$ 梁部材のせん 断耐荷力は二羽らのせん断耐荷力算定式 5)で比較的精度 良く算定することが可能である 9. 表-6に示す計算値[1] は, 式(1)に示す二羽らの棒部材のせん断耐力評価式に より求めた各試験体の計算上のせん断耐力である. 計 算值[1]では，引張鉄筋比を既設部の主筋および補強筋 の合計断面積と両鉄筋の図心位置として求めた有効高 さを用いて算出した.

$$
\begin{aligned}
V_{c}=0.20\left(p_{w} f_{c}^{\prime}\right)^{1 / 3} d^{-1 / 4}[0.75+1.4 /(a / d)] b_{w} d \\
\text { ここに, } b_{w}: \text { 有効幅 }(\mathrm{mm}) \\
d: \text { 有効高さ }(\mathrm{mm}) \\
p_{w}: \text { 引張鉄筋比 } \\
a: \text { せん断スパン }(\mathrm{mm}) \\
f_{c}^{\prime}: \text { コンクリートの圧縮強度 }\left(\mathrm{N} / \mathrm{mm}^{2}\right)
\end{aligned}
$$

表-6 静的載荷試験結果

\begin{tabular}{|c|c|c|c|c|c|c|c|}
\hline $\begin{array}{c}\text { 試 } \\
\text { 験 } \\
\text { 体 }\end{array}$ & $\begin{array}{c}\text { 有効 } \\
\text { 高さ } \\
(\mathrm{mm})\end{array}$ & $a / d$ & $\begin{array}{c}\text { 曲げ } \\
\begin{array}{c}\text { 発生荷重 } \\
(\mathrm{kN})\end{array}\end{array}$ & $\begin{array}{c}\text { せん断 } \\
\text { ひび割れ } \\
\text { 発生荷重 } \\
(\mathrm{kN})\end{array}$ & $\begin{array}{c}\text { 破壊 } \\
\text { 荷重 } \\
(\mathrm{kN})\end{array}$ & $\begin{array}{c}\text { 計算値 } \\
{[1]} \\
(\mathrm{kN})\end{array}$ & $\begin{array}{c}\text { 計算値 } \\
{[2]} \\
(\mathrm{kN})\end{array}$ \\
\hline \hline $\mathrm{SA}$ & 137 & 4.2 & 35 & 150 & 295 & 141 & 305 \\
\hline $\mathrm{SB}$ & 152 & 3.8 & 45 & 155 & 290 & 172 & 423 \\
\hline $\mathrm{SC}$ & 152 & 3.8 & 75 & 215 & 310 & 175 & 426 \\
\hline $\mathrm{SD}$ & 152 & 3.8 & 70 & 170 & 210 & 175 & 428 \\
\hline $\mathrm{SE}$ & 152 & 3.8 & 75 & 155 & 280 & 173 & 423 \\
\hline $\mathrm{SF}$ & 152 & 3.8 & 69 & 175 & 285 & 175 & 426 \\
\hline $\mathrm{SG}$ & 148 & 3.9 & 55 & 170 & 205 & 173 & 365 \\
\hline
\end{tabular}

計算値[1]は，実験值の破壊荷重より過小な值を示し， せん断ひび割れ発生荷重に近い值となった。これは,

表-6 に示すように下面増厚に伴い有効高さが増すこと によって aldが小さくなることに起因するアーチ効果で せん断耐荷力が向上したことにより，実験值の破壊荷 重が計算值より高くなったものと考えられる.

また，せん断ひび割れは，梁端部のハンチ部を貫く もので, 支点のハンチ下端から載荷点方向に発生した. この破壊面は無補強試験体も，補強試験体も同様であ り補強の有無によりせん断ひび割れの発生位置の変化 がない，そのため，増厚により曲げ補強効果とせん断 ひび割れ発生荷重が向上したが，せん断ひび割れ発生 後の終局的なせん断耐荷力は差が生じなかったものと 考えられる.

さらに，表-6 には計算値[2]として式(2)により求めた 梁状化した床版のせん断耐荷力》の算定值を示寸.

$$
P_{s x}=20 B\left(\tau_{\max } \cdot x_{m}+\sigma_{\text {max }} \cdot C_{m}\right)
$$

ここに, $B$ : 梁状化有効幅 $(\mathrm{cm})$

$$
\begin{aligned}
C_{m} & : \text { 主鉄筋断面のかぶり }(\mathrm{cm}) \\
X_{m} & : \text { 主鉄筋断面の中立軸高さ }(\mathrm{cm}) \\
\tau_{\max } & \text { コンクリートの最大せん断応力度 }(\mathrm{N}) \\
\sigma_{\max } & : \text { コンクリートの最大引張応力度 }(\mathrm{N})
\end{aligned}
$$

計算値[2]は無補強試験体の破壊荷重が $295 \mathrm{kN}$ であっ たのに対し $305 \mathrm{kN}$ となり，計算值と実測值は近い精度 といえる. そのため今回の試験体のように梁状化した 床版を想定した梁形状の場合，計算值[2]の方が実測值 に近い值を示寸ものと考えられる，計算值[2]では増厚 後 $1.20 \sim 1.40$ 倍にせん断而荷力が向上するようになった が，既に述べたように破壊面がハンチ部を貫くもので あり，増厚による変化が実験に現れなかったものと考 えられ，下面増厚後における式(2)の計算值[2]は破壊荷 重を過大に評価した結果となっている.

\section{b) 変位性状}

スパン中央点の荷重一変位関係を図-5に示寸. 図-5 の初期の勾配に着目寸ると，表-6 に示すせん断ひび割 れが発生するまでは，増厚によって剛性が向上してい るために変位が抑制されていることが確認できる.

$\mathrm{SB} \sim \mathrm{SD}$ の増厚部モルタルの静弾性係数は表-5 に示し たとおり 1.91〜2.42(×104 $\left.\mathrm{N} / \mathrm{mm}^{2}\right)$ 程度で，SE〜SG の 1.67 $\sim 1.82\left(\times 10^{4} \mathrm{~N} / \mathrm{mm}^{2}\right)$ と比較して高い. 静弾性係数の高い 増厚材料を用いた $\mathrm{SB} \sim \mathrm{SD}$ は，せん断ひび割れ発生後 の変位増加が急速であるが，静弾性係数の低い増厚材 料を用いた SE〜SG は，せん断ひび割れ発生後も荷重 の増加とともに変位が比較的緩やかに変動している. 
いずれにしても，せん断ひび割れ発生直後は，増厚 部分が負担していた耐荷力が既設 RC 梁に分配されるた め，無補強の $\mathrm{RC}$ 梁 $(\mathrm{SA})$ に荷重一変位曲線は近づく傾向 にある。

\section{c) 鉄筋ひずみの性状}

$\mathrm{RC}$ 梁の支間中央部における主鉄筋および補強鉄筋の

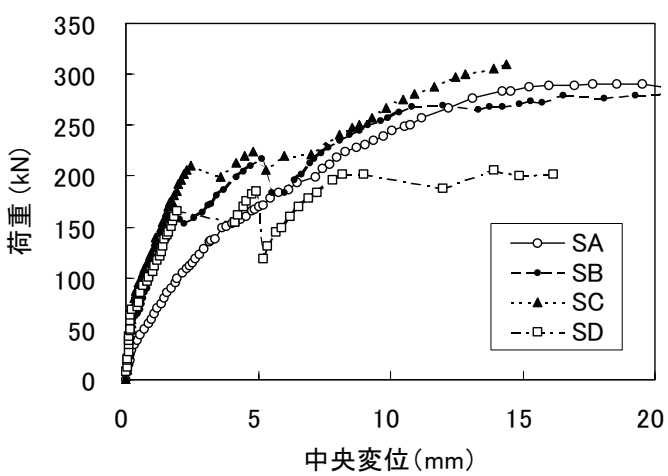

(a) 試験体 SA SD
ひずみを図-6 および図-7 に示す，図-6 および図-7 より, せん断ひび割れが発生するまでは，主鉄筋に生じる応 力を補強鉄筋が分担していることが確認できる。これ らのことから，せん断ひび割れが発生する以前におい ては，下面増厚による曲げ補強効果が確認された。

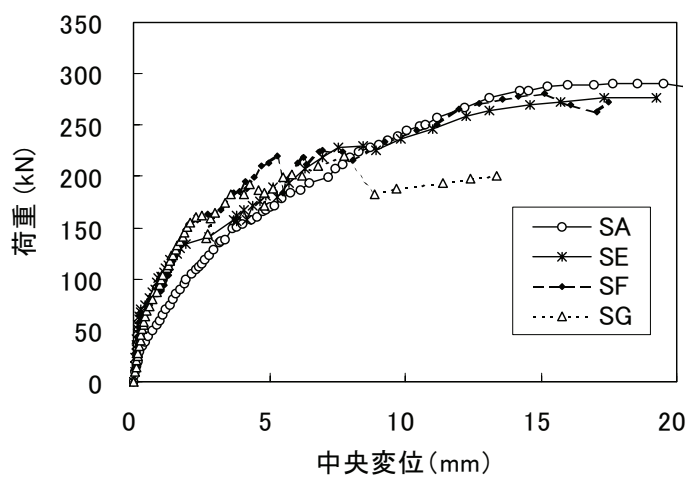

(b) 試験体 SA,SE〜SG

図-5 荷重一中央変位の関係

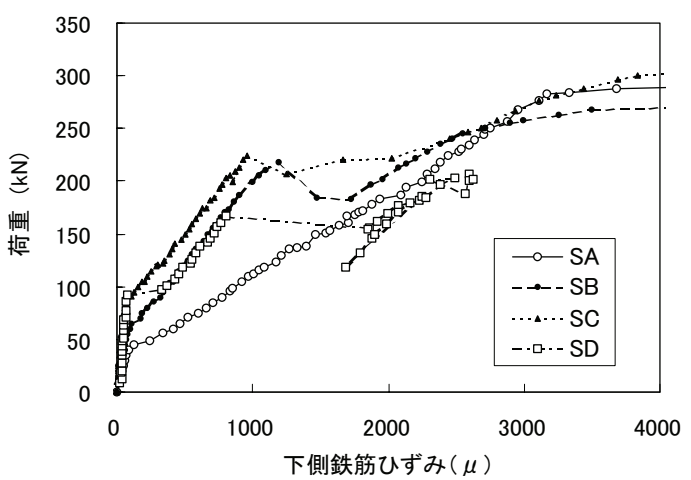

(a) 試験体 $\mathrm{SA} \sim \mathrm{SD}$

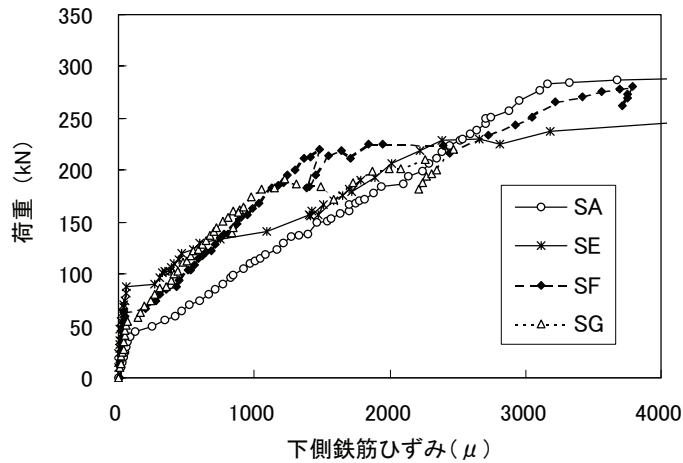

(b) 試験体 SA,SE〜SG

図-6＼cjkstart荷重一主鉄筋ひずみの関係

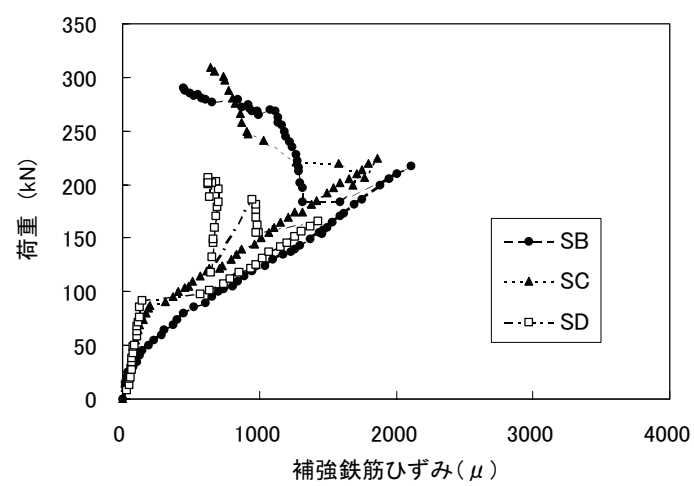

(a) 試験体 $\mathrm{SB} \sim \mathrm{SD}$

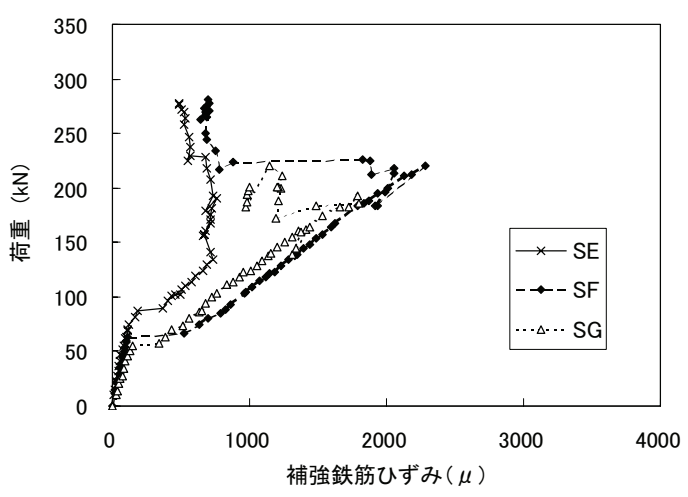

(b) 試験体 $\mathrm{SE} \sim \mathrm{SG}$

図-7＼cjkstart荷重一補強鉄筋ひずみの関係 


\section{(5) 疲労試験結果}

\section{a)載荷回数の比較}

繰返し載荷荷重の最大值と載荷回数を表-7に示す。無 補強試験体（FA）は表-6に示す静的破壊荷重(SA： $295 \mathrm{kN})$ の $40 \%$ である $118 \mathrm{kN}$ の59万回載荷で疲労破壊した が，下面増厚補強試験体(FB～FG)は $118 \mathrm{kN}$ の 100 万回載荷 時点で破壊しなかったため，50\%(145kN)に荷重を上げ て疲労破壊するまで載荷した。なお，FCはSCの静的破 壊荷重(310kN)の50\%である $155 \mathrm{kN}$ 荷重を上げている.

表-7には式(3)の土木学会コンクリート標準示方書[構造 性能照査編]のせん断補強鉄筋を用いない棒部材の設計 せん断疲労耐力の評価式 ${ }^{8}$ （以下，示方書式と記す）を 参考に荷重 $118 \mathrm{kN}$ に換算した回数と無補強試験体(FA)の 疲労寿命に対する比を示している.

$$
V_{r c d}=V_{c}\left(1-\frac{V_{p d}}{V_{c}}\right)\left(1-\frac{\log N}{11}\right)
$$

ここに， $V_{r c d}$ : せん断疲労耐力 $(\mathrm{kN})$

$V_{c}:$ 世ん断而力 $(\mathrm{kN})$

$V_{p d}$ : 永久荷重作用時の設計せん断力 $(\mathrm{kN})$

$N$ : 疲労寿命

表-7より，いずれの下面増厚補強によっても疲労耐久 性が向上することが確認できる。 また，補強試験体(FB 〜 FG)は無補強試験体(FA)に比べて $118 \mathrm{kN}$ に換算した疲労 載荷回数が計算上は8～26倍の值を示していることが判 る. なお, 増厚材料および増厚構造の違いによって疲労 耐久性の向上効果も異なることも示唆される.

\section{b) 疲労寿命推定曲線との比較}

表-7 に記載した示方書式に基づく換算回数と既往の 疲労寿命推定曲線との比較を図-8 に示す. 図-8 の示方 書式は，静的載荷試験で得られた無補強試験体 $(\mathrm{SA})$ のせ ん断耐力の実測值を示方書式に代入した S-N曲線であり, 松井式は，同様の実測值を式(4)に示す貫通ひび割れに よって梁状化した RC 床版に対する S-N 関係式 7に代入 した S-N曲線である.

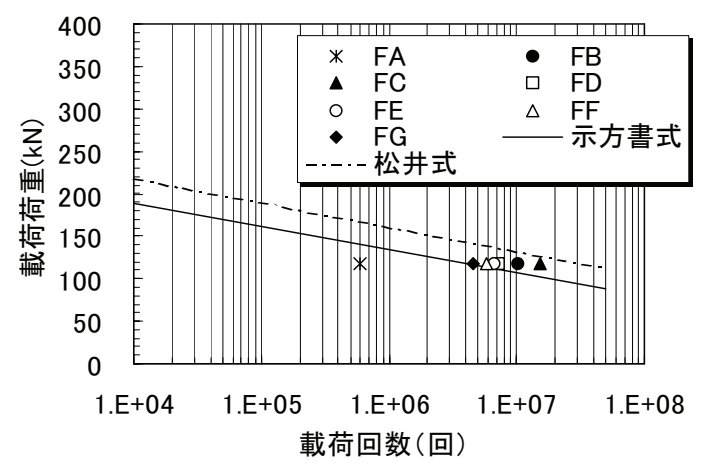

図-8 疲労寿命推定曲線との比較

$$
\log \left(\frac{S_{0}}{P_{S x^{\prime}}}\right)=-0.07835 \cdot \log N^{\prime}+\log 1.520
$$

ここに， $S_{0}$ : 換算荷重 $(\mathrm{kN})$

$P_{s x}{ }^{\prime}$ : 梁状化有効幅の押抜きせん断而力 $(\mathrm{kN})$ $N^{\prime}:$ 等価繰り返し回数

図-8より，今回の実験值は示方書式と松井式の間に 分布しており，これらの既往の算定式により疲労寿命を 評価できる. なお，松井式による疲労寿命推定について は 4 章で詳述する.

\section{c) 中央変位および剛性の変化}

図-9 に, 疲労載荷試験での載荷回数とスパン中央変 位との関係を示す. 図-9より，無補強試験体(FA)に比べ て下面増厚試験体 $(\mathrm{FB} \sim \mathrm{FG})$ は剛性が向上し中央変位の 増加が抑制されており補強効果が確認できる.

\section{d) 疲労破壊性状}

疲労載荷試験での最終的な破壊は，写真-2 に示すよ うにハンチ部近傍からのひび割れによる破壊であり，無 補強試験体（FA）と比較すると下面増厚試験体 $(\mathrm{FB} \sim$ FG)は下面増厚部にせん断ひび割れが貫通しており，破 壊モードが異なる。また，静的載荷試験での最終的な破 壊は，写真-1に示したように，支点部からのせん断ひび

\begin{tabular}{|c|c|c|c|}
\hline 試験体 & $\begin{array}{l}\text { 繰返し最大 } \\
\text { 荷重 }(\mathrm{kN})\end{array}$ & 載荷回数 & $\begin{array}{l}118 \mathrm{kN} \text { 換算回数 } \\
\text { (比) }\end{array}$ \\
\hline FA & 118 & 59万回（破壊） & $\begin{array}{c}\text { 59万回 } \\
\text { (1) }\end{array}$ \\
\hline \multirow{2}{*}{ FB } & 118 & 100 万回 & \multirow{2}{*}{$\begin{array}{c}1007 \text { 万回 } \\
\text { (17) }\end{array}$} \\
\hline & 145 & 94万回 (破壊) & \\
\hline \multirow{2}{*}{$\mathrm{FC}$} & 118 & 100 万回 & \multirow{2}{*}{$\begin{array}{c}1546 \text { 万回 } \\
\text { (26) }\end{array}$} \\
\hline & 155 & 72 万回 (破壊) & \\
\hline \multirow{2}{*}{ FD } & 118 & 100 万回 & \multirow{2}{*}{$\begin{array}{c}727 \text { 万回 } \\
\text { (12) }\end{array}$} \\
\hline & 145 & 65 万回 (破壊) & \\
\hline \multirow{2}{*}{$\mathrm{FE}$} & 118 & 100 万回 & \multirow{2}{*}{$\begin{array}{l}659 \text { 万回 } \\
\text { (11) }\end{array}$} \\
\hline & 145 & 58万回 (破壊) & \\
\hline \multirow{2}{*}{$\mathrm{FF}$} & 118 & 100 万回 & \multirow{2}{*}{$\begin{array}{c}573 \text { 万回 } \\
\text { (10) }\end{array}$} \\
\hline & 145 & 49万回（破壊） & \\
\hline \multirow{2}{*}{ FG } & 118 & 100 万回 & \multirow{2}{*}{$\begin{array}{c}457 \text { 万回 } \\
\text { (8) }\end{array}$} \\
\hline & 145 & 37 万回（破壊） & \\
\hline
\end{tabular}

表-7 載荷荷重と載荷回数

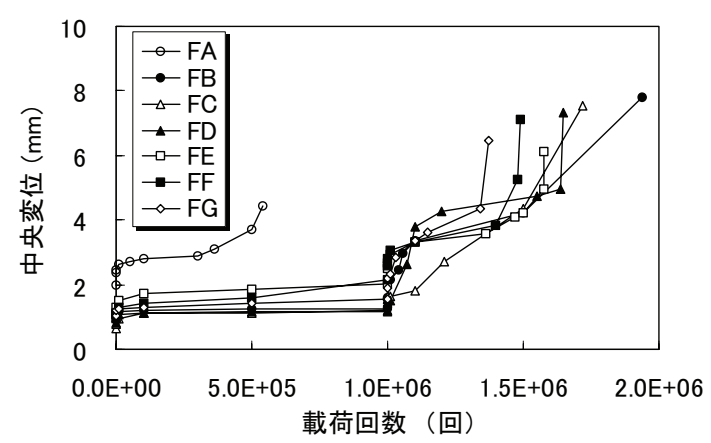

図-9 載荷回数と中央変位の関係 


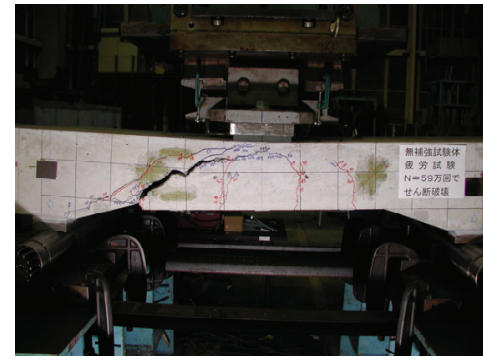

(a) 試験体FA

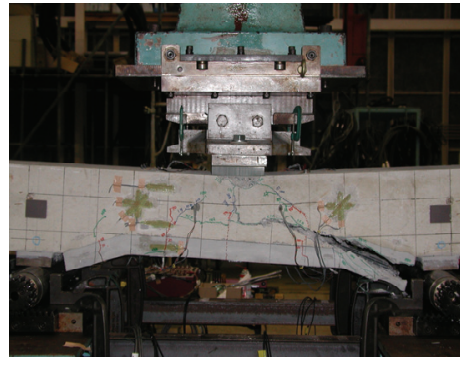

(b) 試験体FB

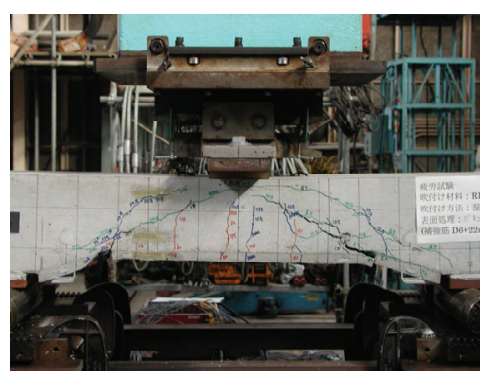

(c) 試験体FG

写真-2 疲労試験体の破壊状況の例

表-8 RC 床版試験体の諸元

\begin{tabular}{|c|c|c|c|c|c|c|c|}
\hline $\begin{array}{l}\text { 試験体 } \\
\text { 種別 }\end{array}$ & $\begin{array}{l}\text { 寸法 } \\
(\mathrm{mm})\end{array}$ & $\begin{array}{l}\text { 支間 } \\
(\mathrm{mm})\end{array}$ & $\begin{array}{l}\text { 主鉄筋 } \\
(\mathrm{mm})\end{array}$ & $\begin{array}{l}\text { 配力鉄筋 } \\
(\mathrm{mm})\end{array}$ & $\begin{array}{c}\text { 補強方法 } \\
\text { (増厚部の使用材料) }\end{array}$ & $\begin{array}{c}\text { 補強鉄筋 } \\
(\mathrm{mm})\end{array}$ & 表面処理工法 \\
\hline 床版 A & \multirow{3}{*}{$\begin{array}{c}3000 \\
\times \\
7000 \\
\times \\
180\end{array}$} & \multirow{3}{*}{2500} & \multirow{3}{*}{$\begin{array}{c}\text { 上側（圧縮側） } \\
\text { D16@300 } \\
\text { 下側（引張側） } \\
\text { D16@150 }\end{array}$} & \multirow{3}{*}{$\begin{array}{c}\text { 上側 (圧縮側) } \\
\text { D10@300 } \\
\text { 下側 (引張側) }\end{array}$} & 無補強 & - & - \\
\hline 床版 B & & & & & $\begin{array}{c}\text { 厚さ } 50 \mathrm{~mm} \text { の下面増厚 } \\
\text { (ポリマーセメントモルタル A) }\end{array}$ & D10@100 & ブラスト工法 \\
\hline 床版 C & & & & & $\begin{array}{c}\text { 厚さ } 22 \mathrm{~mm} \text { の下面増厚 } \\
\text { (ポリマーセメントモルタル A) }\end{array}$ & D6@45 & ブラスト工法 \\
\hline
\end{tabular}

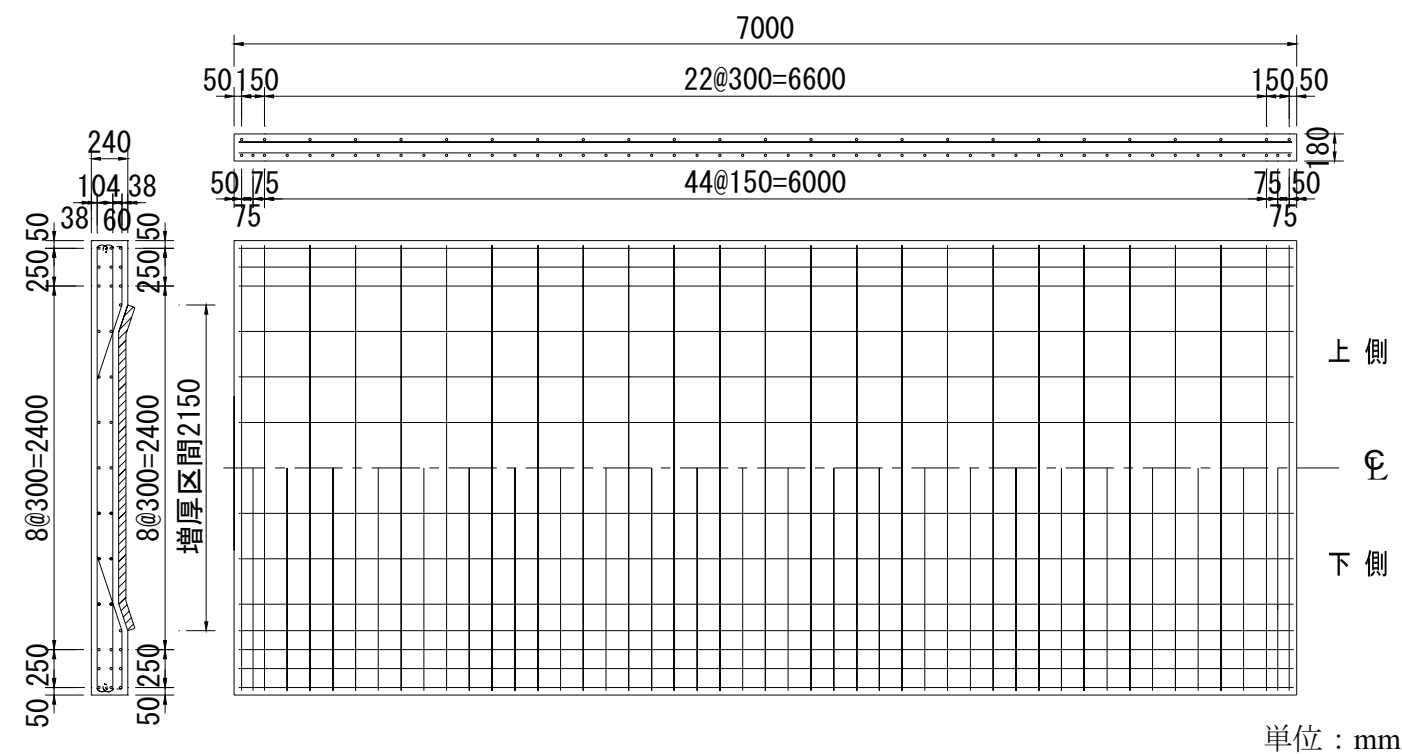

図-10 RC床版試験体の形状

割れによる破壊であり，下面増厚部にせん断ひび割れが 貫通していない. 静的試験と疲労試験では下面増厚によ るせん断補強効果に違いがあるため破壊モードに差異が 生じたと推測される.

\section{RC床版の輪荷重走行試験}

\section{(1) 試験体の諸元}

実物大のRC床版試験体を用いて，車両の輪荷重の走 行を再現した輪荷重走行試験を実施した。輪荷重走行試 験で用いたRC床版試験体は，昭和39年の鋼道路橋設計
示方書に基づいて設計された表-8に示す諸元のものとし， 主鉄筋方向の床版支間 $2500 \mathrm{~mm}$ で2辺単純支持した．表-8 に示すように，床版Aは無補強床版であり，床版Bおよ び床版Cは50mmおよび22 $\mathrm{mm}$ の厚さで下面増厚した床版 である．すなわち床版Bは前章で示した梁試験体(SF, FF) に，床版Cは梁試験体(SG, FG)にそれぞれ相当するもの である．補強鉄筋量は，床版Bと床版Cで等しくなるよ うに補強鉄筋間隔を調整した。

図-10に床版試験体の形状を示す。既往の輪荷重走行 試験9)では床版厚を190mmとし支点部にハンチを設けて いないが，今回の試験では，前述したRC梁試験体と同 様に床版厚を180mmとし，支点部にハンチを設けている. 
試験時の鉄筋，コンクリートおよび増厚部モルタル の強度試験結果を表-9〜表-11に示す.

\section{(2) 試験方法}

輪荷重走行試験は， RC 床版試験体の上面に $500 \mathrm{~mm} \times$ $200 \mathrm{~mm}$ の載荷ブロックを 1 列に並べた軌道上を幅 $500 \mathrm{~mm}$ の鉄輪が $3 \mathrm{~m}$ の範囲 $( \pm 1.5 \mathrm{~m})$ を往復して載荷す るものとした．載荷荷重の設定は，既往の階段状荷重漸 増載荷による方法 ${ }^{9)}$ と同様に $157 \mathrm{kN}$ から開始し，表-12 に示すように，1 ステップあたり 4 万回の輪荷重走行毎 に載荷荷重を約 $20 \mathrm{kN}$ ずつ増加させる方法とした。

\section{(3) 試験結果}

\section{a) 破壊時走行回数の比較}

図-10 に階段載荷における載荷荷重と破壊時走行回数 の関係を示す。

表-9 鉄筋の引張試験結果

\begin{tabular}{|c|c|c|c|}
\hline $\begin{array}{c}\text { 鉄筋 } \\
\text { 種類 }\end{array}$ & $\begin{array}{c}\text { 降伏点 } \\
\left(\mathrm{N} / \mathrm{mm}^{2}\right)\end{array}$ & $\begin{array}{c}\text { 引張強さ } \\
\left(\mathrm{N} / \mathrm{mm}^{2}\right)\end{array}$ & $\begin{array}{c}\text { 静弾性係数 } \\
\left(\times 10^{4} \mathrm{~N} / \mathrm{mm}^{2}\right)\end{array}$ \\
\hline \hline $\mathrm{D} 6$ & 427 & 545 & 19.2 \\
\hline $\mathrm{D} 10$ & 380 & 532 & 18.9 \\
\hline $\mathrm{D} 13$ & 358 & 516 & 19.2 \\
\hline $\mathrm{D} 16$ & 352 & 520 & 19.0 \\
\hline
\end{tabular}

表-10 コンクリートの強度試験結果

\begin{tabular}{|c|c|c|c|}
\hline 試験体 & $\begin{array}{c}\text { 圧縮強度 } \\
\left(\mathrm{N} / \mathrm{mm}^{2}\right)\end{array}$ & $\begin{array}{c}\text { 引張強度 } \\
\left(\mathrm{N} / \mathrm{mm}^{2}\right)\end{array}$ & $\begin{array}{c}\text { 静弾性係数 } \\
\left(\times 10^{4} \mathrm{~N} / \mathrm{mm}^{2}\right)\end{array}$ \\
\hline \hline 床版 $\mathrm{A}$ & 32.6 & 2.96 & 2.38 \\
\hline 床版 $\mathrm{B}$ & 33.6 & 2.82 & 2.25 \\
\hline 床版 $\mathrm{C}$ & 34.3 & 2.75 & 2.35 \\
\hline
\end{tabular}

表-11 増厚部モルタルの強度試験結果

\begin{tabular}{|c|c|c|c|c|}
\hline 試験体 & $\begin{array}{c}\text { 压縮強度 } \\
\left(\mathrm{N} / \mathrm{mm}^{2}\right)\end{array}$ & $\begin{array}{c}\text { 引張強度 } \\
\left(\mathrm{N} / \mathrm{mm}^{2}\right)\end{array}$ & $\begin{array}{c}\text { 静弾性係数 } \\
\left(\times 10^{\mathrm{N}} \mathrm{Nm} \mathrm{mm}^{2}\right)\end{array}$ & $\begin{array}{c}\text { 増厚材料 } \\
(\text { モルタル })\end{array}$ \\
\hline \hline 床版 B & 47.4 & 3.85 & 2.52 & $\begin{array}{c}\text { ポリマーセメント } \\
\text { モルタル }\end{array}$ \\
\hline 床版 $\mathrm{C}$ & 43.5 & 3.07 & 2.48 & $\begin{array}{c}\text { ポリマーセメント } \\
\text { モルタル } \mathrm{A}\end{array}$ \\
\hline
\end{tabular}

表-12 載荷荷重の設定

\begin{tabular}{|c|c|c|}
\hline $\begin{array}{c}\text { 載荷 } \\
\text { ステップ }\end{array}$ & $\begin{array}{c}\text { 載荷荷重 } \\
(\mathrm{kNN})\end{array}$ & $\begin{array}{c}\text { 総走行回数 } \\
(\text { 万回) }\end{array}$ \\
\hline $1 \mathrm{~N}$ & 157 & 4 \\
\hline $2 \mathrm{~N}$ & 177 & 8 \\
\hline $3 \mathrm{~N}$ & 196 & 12 \\
\hline $4 \mathrm{~N}$ & 216 & 16 \\
\hline $5 \mathrm{~N}$ & 235 & 20 \\
\hline $6 \mathrm{~N}$ & 255 & 24 \\
\hline $7 \mathrm{~N}$ & 275 & 28 \\
\hline $8 \mathrm{~N}$ & 294 & 32 \\
\hline $9 \mathrm{~N}$ & 314 & 36 \\
\hline $10 \mathrm{~N}$ & 333 & 40 \\
\hline $11 \mathrm{~N}$ & 353 & 44 \\
\hline $12 \mathrm{~N}$ & 373 & 48 \\
\hline $13 \mathrm{~N}$ & 392 & 52 \\
\hline $14 \mathrm{~N}$ & 412 & 56 \\
\hline
\end{tabular}

図-11 には，(独)土木研究所（以下，土研と記す）で 行われた同様の輪荷重階段載荷試験結果 9 ${ }^{9}$ も併せて記載 した．床版 A と諸元が類似している土研の供試体は 「RC39 土研」として表記しているが，床版 A が $255 \mathrm{kN}$ の 21.54 万回で破壊しているの対して，「RC39土研」は $157 \mathrm{kN}$ の 2.7 万回で破壊している. 試験結果が異なって いる要因は，輪荷重走行試験機の構造上の違いとハンチ 構造の有無による影響であると考えられる.

また，平成 8 年の道路橋示方書に基づいて設計された 土研の供試体は「H8 土研」と表記しているが，「H8 土 研」は $275 \mathrm{kN}$ の 25.6 万回で破壊しており, 床版 A は

「H8 土研」に近い結果となっている. 一方, 下面増厚 した床版 Cおよび床版 B は，それぞれ，373kNの 45.1 万 回と $412 \mathrm{kN}$ の 53.4 万回で破壊しており, 無補強の床版 $\mathrm{A}$ と比較して, 疲労耐久性が向上していることが確認でき る.なお，土研において実施された FRP グリッドを補 強筋とした下面増厚工法を施した供試体の試験結果を

「FRPグリッド土研」と表記しているが，「FRP グリッ ド土研」は，「RC39 土研」の 4 段階上で破壊している. 一方，今回の試験結果では，鉄筋を補強筋に用いた下面 増厚工法を施した床版 $\mathrm{B}$ および床版 $\mathrm{C}$ は, 無補強試験 体である床版 A に比べて 6段階以上で破壊している.

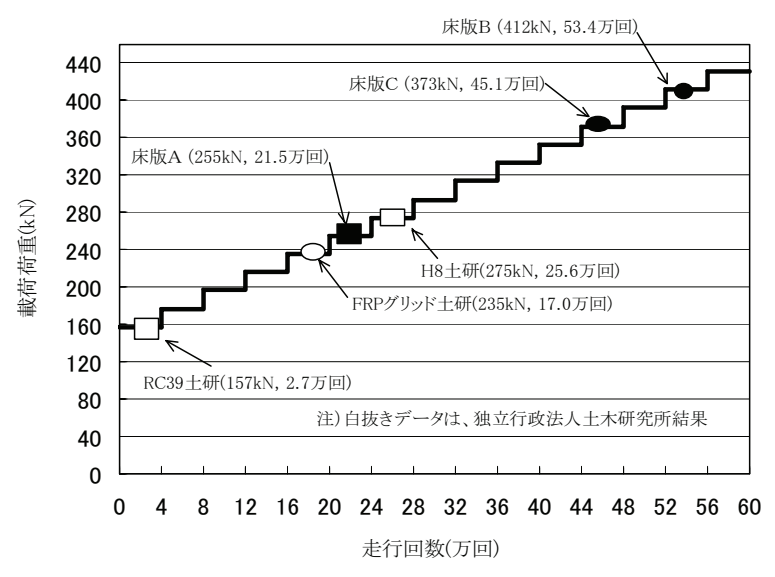

図-11 破壊時走行回数と破壊荷重の関係

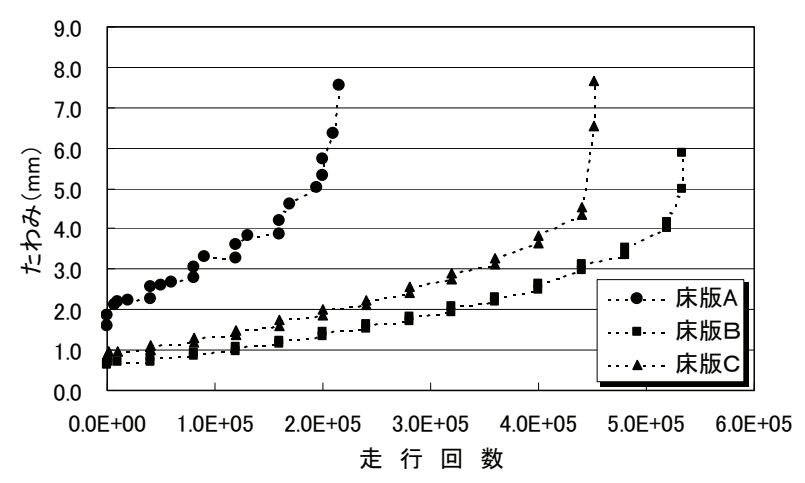

図-12 走行回数と活荷重たわみの関係 
以上より，階段状荷重漸増載荷による輪荷重走行試 験の結果，無補強床版に比べて下面増厚した RC 床版は 疲労耐久性が向上することが確認できた.

\section{b) 走行回数と活荷重たわみの関係}

図-12 に，走行回数と各床版中央の活荷重たわみとの 関係を示す．活荷重たわみが $4 \mathrm{~mm}$ を超えると急増して 破壊に至るという傾向を示しており，活荷重たわみの $4 \mathrm{~mm}$ は床版としての変形性能の限界值と示唆される. また, 載荷ステップ $3 \mathrm{~N}$ （総走行回数 12 万回）以下で, 無補強の床版 A と比較寸ると, 下面増厚補強された床 版 B および床版 C は，たわ久量が 3〜4 割に低減してお り, 下面増厚による補強効果が確認できる.

\section{c) RC 床版供試体の破壊性状}

図-13 に，破壊時の床版下面のひび割れ発生状況を示 す．いずれの試験体も，破壊時のひび割れは亀甲状であ り, 同様な傾向を示している. ひび割れ本数は, 床版 C が床版 A および B に比べて多く, ひび割れが分散して いる傾向を示している。 これは，床版 C の補強鉄筋間 隔を床版 B に比べて小さく設置している影響と考えら れる。なお，ひび割れ幅は無補強の床版 A が最大 $0.8 \mathrm{~mm}$ であったのに対し，下面増厚した床版 Bおよび C は $0.2 \mathrm{~mm}$ 以下であり, 載荷範囲近傍（幅 $0.8 \mathrm{~m} \times$ 長さ $3 \mathrm{~m}$ の範囲）の床版下面におけるひび割れ密度を算出すると， 床版 A および B は $15\left(\mathrm{~m}^{2} \mathrm{~m}^{2}\right)$ であり，床版 C は $21\left(\mathrm{~m} / \mathrm{m}^{2}\right)$ であった。

また，床版試験体は，試験終了後に橋軸方向および橋 軸直角方向に切断した．橋軸直角方向は，押抜きせん断
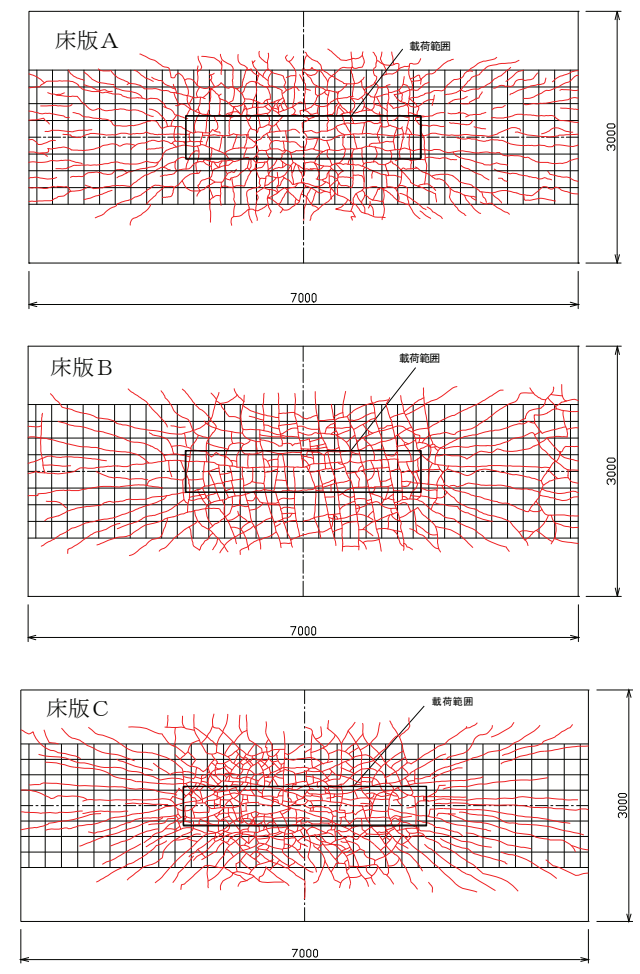

図-13 破壊時の床版下面のひひ割れ発生状況
破壊した範囲のほぼ中心を切断し，橋軸方向は，鉄筋位 置を避けるため床版中心から $50 \mathrm{~mm}$ の位置を切断した.

橋軸直角方向の切断面のひび割れ図および状況写真を 図-14 および写真-3 に示す. 橋軸直角方向の切断面を見 ると, 載荷幅 $(500 \mathrm{~mm})$ の直下で上側圧縮鉄筋に沿って水 平方向ひび割れが発生している.これは載荷直下の鉄筋 かぶりに発生する輪荷重走行試験特有のひび割れである. いずれの試験体も橋軸直角方向の押抜きせん断ひび割れ は，概ね左右対称に発生しており，せん断破壊面の角度 は 30 40 程度であった. 補強試験体では, せん断ひ び割れが増厚界面に沿って支点側へ進展し, 増厚部が載 荷位置を中心にしてドーナツ状に剥離する状況を示した。 また，無補強床版は押抜きせん断破壊により床版下面に せん断ひび割れによる段差が見られるが，下面増厚床版 では増厚部にはせん断ひび割れは見られず，増厚部が面 的に剥離し, 増厚端部に段差が生じる特徵を示した。

\section{d) S-N 関係による疲労耐久性の比較}

床版試験体の疲労耐久性を比較するために，今回の試 験結果と前述した土研の試験結果 ${ }^{9)}$ および JH で過去に 実施した平成 8 年の道路橋示方書に基づいて設計された 供試体の試験結果（「H8JH」と表記）を $157 \mathrm{kN}$ に換算し た等価繰返し載荷回数および無次元化した S-N 曲線 》 （松井式）を併記して図-15に示す.

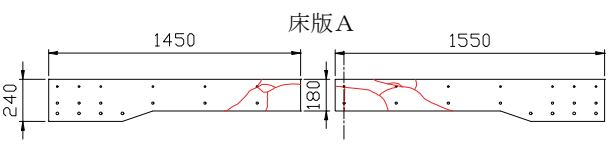

床版 B
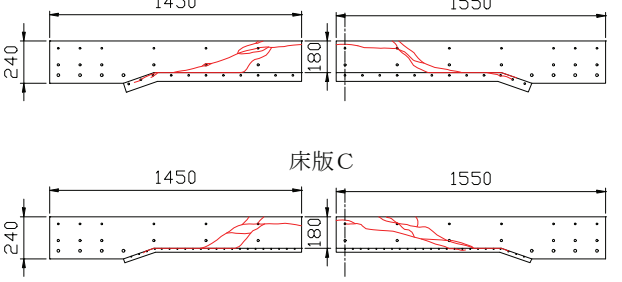

図-14 橋軸直角方向のひび割れ図
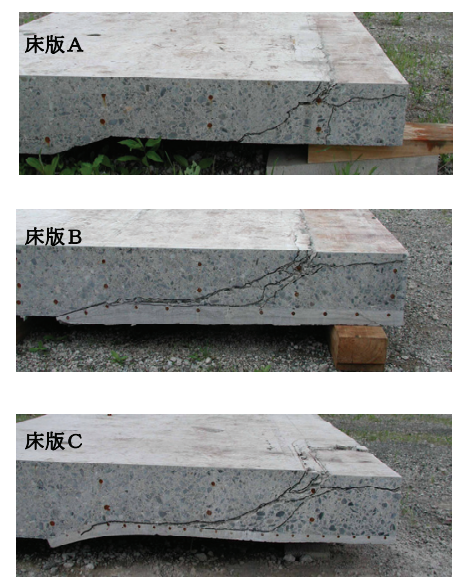

写真-3 橋軸直角方向のひび割れ状況 
表-13 RC床版試験体の等価繰返し回数と押抜きせん断而荷力

\begin{tabular}{|c|c|c|c|c|c|c|c|}
\hline 試験体 & $\begin{array}{c}\text { 終局荷重 } \\
(\mathrm{kN})\end{array}$ & $\begin{array}{c}\text { 総繰返し回数 } \\
N \\
N\end{array}$ & $\begin{array}{c}\text { 換算荷重 } \\
(\mathrm{kN})\end{array}$ & $\begin{array}{c}\text { 等価繰返し回数 } \\
N^{\prime}\end{array}$ & $\begin{array}{c}\text { 押抜きせん断 } \\
\text { 耐荷力 } \\
P_{s^{\prime}}{ }^{\prime}(\mathrm{kN}) \\
\end{array}$ & $\begin{array}{c}\text { 松井式 } \\
\text { せん断而何力 } \\
P_{s x}(\mathrm{kN}) \\
\end{array}$ & $P_{s x} / / P_{s x}$ \\
\hline 床版A & 255 & 215,000 & 250 & 42,054 & 379 & 324 & 1.17 \\
\hline 床版B & 412 & 534,000 & 250 & $33,104,862$ & 639 & 532 & 1.20 \\
\hline 床版C & 373 & 451,000 & 250 & $7,837,011$ & 570 & 448 & 1.27 \\
\hline
\end{tabular}

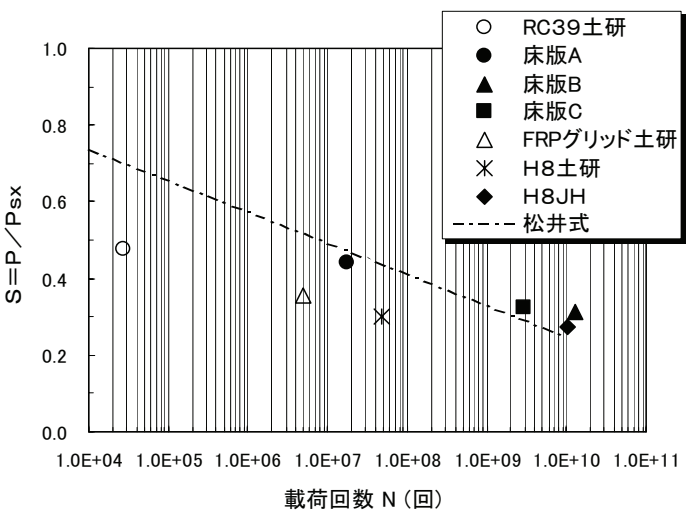

図-15 無次元化した S-N関係

図-15に示すように土研の試験結果は松井式の下方に 位置しており，今回の試験結果は松井式の近傍および上 方に位置していることが判る。また，無補強床版 （RC39土研，床版A）に比べて補強床版（FRPグリッド 土研，床版Bおよび床版C）の載荷回数は，平成8年の道 路橋示方書に基づいて設計された床版（H8土研， H8JH）の載荷回数近くまで増加していることが判る.

\section{4. 疲労耐久性に関する考察}

\section{(1) 下面増厚した $\mathrm{RC}$ 床版の疲労耐久性}

表-13 に床版供試体の等価繰返し回数と押抜きせん断 耐荷力との関係を示す. 前述した床版の輪荷重走行試験 では輪荷重 $157 \mathrm{kN} \sim 412 \mathrm{kN}$ まで段階的に繰返し荷重を載 荷している。そのため同一の輪荷重で繰返し載荷実験を した場合の疲労耐久性（等価繰返し回数）を表-13 に付 記した．道路橋床版の輪荷重繰返しによる劣化を促進さ せている一要因として設計荷重を大きく上回る過積載車 両の輪荷重があげられる．実橋の通行車両では最大の過 積載車両として 1 輪あたり $250 \mathrm{kN}$ が計測されている ${ }^{10)}$. そのため等価繰返し回数の換算荷重を $250 \mathrm{kN}$ とた。等 価繰返し回数の計算は式(5)に示す松井の提案式 7)を用い た. 式(5)中の指数 12.753 は図-15 の松井式の傾きを示し ている．本実験結果がこの直線近傍に分布することから， 本計算では指数として 12.753 を使用して妥当であると判 断した.
表-14 RC 梁試験体の等価繰返し回数と押抜きせん断而荷力

\begin{tabular}{|c|r|r|r|r|r|}
\hline $\begin{array}{c}\text { 試 } \\
\text { 験 } \\
\text { 体 }\end{array}$ & $\begin{array}{c}\text { 静的 } \\
\text { 而荷力 } \\
(\mathrm{kN})\end{array}$ & $\begin{array}{c}\text { 総繰返し } \\
\text { 回数 } \\
N\end{array}$ & $\begin{array}{c}\text { 換算 } \\
\text { 荷重 } \\
(\mathrm{kN})\end{array}$ & $\begin{array}{c}\text { 等価繰返し } \\
\text { 回数 } \\
N^{\prime}\end{array}$ & $\begin{array}{c}\text { 押抜きせん } \\
\text { 断而荷力 } \\
P_{s x}{ }^{\prime}(\mathrm{kN})\end{array}$ \\
\hline \hline FA & 295 & 590,000 & 118 & 590,000 & 220 \\
\hline FB & 290 & $1,940,000$ & 118 & $14,038,799$ & 282 \\
\hline FC & 310 & $1,720,000$ & 118 & $24,394,076$ & 294 \\
\hline FD & 210 & $1,650,000$ & 118 & $10,016,191$ & 275 \\
\hline FE & 280 & $1,580,000$ & 118 & $9,045,217$ & 272 \\
\hline FF & 285 & $1,490,000$ & 118 & $7,795,821$ & 269 \\
\hline FG & 205 & $1,370,000$ & 118 & $6,132,293$ & 264 \\
\hline
\end{tabular}

$\sum N_{i}=\left(\frac{S_{0}}{S_{i}}\right)^{12.753} \times N_{0}$

ここに, $N_{i}$ : 載荷回数(回)

$S_{0}:$ 換算荷重 $(\mathrm{kN})$

$S_{i}:$ 載荷荷重 $(\mathrm{kN})$

$N_{0}:$ 換算回数(回)

換算荷重 $250 \mathrm{kN}$ の等価繰返し回数から押抜きせん断而讨 荷力 $P_{s x}$ 'を前述した式(4)より算定した。算定した $P_{s x}$ 'を 表-13 に示す.

表-13 には，前述した式(2)による梁状化した床版の $P_{s x}$ を付記した，2 章で述べたように， $\mathrm{RC}$ 梁の静的載荷試 験では破壊面がハンチ部を貫くものであり，式(2)は下 面増厚による補強効果を過大評価していたが， $\mathrm{RC}$ 床版 の輪荷重走行試験では，表-13 に示すように $250 \mathrm{kN}$ に換 算した等価繰返し回数から求めた押抜きせん断耐荷力 $P_{s x}$ ' 1 床版の断面形状から求まる梁状化した床版の押抜 きせん断而荷力 $P_{s x}$ と同等以上のせん断而何力となって いる.よって, $\mathrm{RC}$ 床版の輪荷重走行試験に関しては, 式(2)により下面増厚による補強効果を評価できるもの と考えられ，今回の輪荷重走行試験により得られた下面 増厚床版の疲労耐久性は下面増厚床版が有する計算上の 押抜きせん断而荷力 $P_{s x}$ に相当する疲労耐久性と同等以 上のものを有することが確認された。

\section{(2) 下面増厚した RC 梁の疲労耐久性}

表-14 に 2 章で行った $\mathrm{RC}$ 梁の定点載荷試験における 無補強試験体の静的而渮力の $40 \%$ に相当する換算荷重 $118 \mathrm{kN}$ に対する等価繰返し回数 $N^{\prime}$ を式(5)を用いて算定し, 

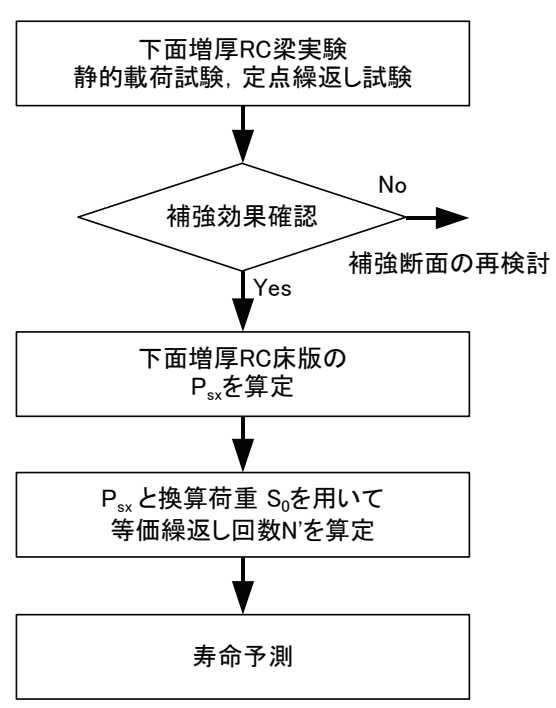

図-16 下面増厚床版の疲労耐久性照査手法

さらに，等価繰返し回数から押抜きせん断耐荷力 $P_{\mathrm{sx}}$ 'を 算定した結果を示寸．等価繰返し回数に対する押抜きせ 儿断而荷力は無補強試験体(FA)に比べて下面増厚補強試 験体(FB〜FG)は向上しており, 輪荷重走行試験の結果と 同様に下面増厚による補強効果が確認できた。

なお，2 章で述べたように静的載荷試験では破壊面が ハンチ部を貫くものであり，下面増厚による補強効果が 静的耐荷力には現れていないが， RC 梁の疲労試験を実 施することによって下面増厚後の疲労耐久性の向上が確 認できる結果となっている.

以上より，本研究で用いたせん断破壞型の $\mathrm{RC}$ 梁の定 点載荷による疲労試験で疲労耐久性の向上が確認された 場合， RC 梁と同断面で下面増厚補強した床版の押抜き せん断耐荷力に相当する疲労耐久性を発揮することが推 定できるものと考えられる.

\section{(3) 下面増厚床版の疲労耐久性照査}

図-16に下面増厚床版の疲労耐久性照査手法を示寸.

最初に，下面増厚した $\mathrm{RC}$ 梁の静的載荷試験および定 点繰返し載荷試験を行い, 下面増厚補強後の疲労耐久性 の向上を簡易な試験方法により確認する.

繰返し載荷試験結果から等価繰返し回数が補強前と比 較して向上していることから補強効果が確認された場合, RC梁実験より疲労耐久性を有寸ることが確認されたこ とから，同一断面での下面増厚床版の押抜きせん断耐荷 力 $P_{s x}$ を求める. その押抜きせん断耐荷力 $P_{s x}$ と換算荷重 $S_{0}$ を用いて等価繰返し回数 $N$ を算定する. 換算荷重 $S_{0}$ は, 実橋で計測される過積載車両の輪荷重を用いる.

最後に，等価繰返し回数を換算荷重 $S_{0} の$ 年間通行量で 除し，破壊までの年数を算定する．算定值が下面増厚補
強床版の寿命となる.

なお，床版の疲労耐久性の性能評価方法としては，実 物大相当の床版試験体による輪荷重走行試験が既往の実 験デー夕数も多く信頼性が高いため, 今回提案した下面 増厚RC梁実験は, 輪荷重走行試験の前段で梁状化した $\mathrm{RC}$ 床版の疲労寿命予測を簡易に行うための性能評価試 験として採用寸るのが望ましいと思われる.

\section{5. 結論}

本研究は，RC 梁試験体を用いた定点載荷試験および $\mathrm{RC}$ 床版試験体を用いた輪荷重走行試験を実施し，下面 増厚工法の補強効果とその疲労耐久性照查方法について 実験的に検討したものである. 本研究で得られた知見を 以下に示す.

(1) RC 梁の静的載荷試験の結果, せん断ひび割れ発生以 前においては，下面増厚補強効果として曲げ岡性が向上 した.

(2) RC 梁の疲労試験の結果, 下面増厚補強によってせん 断破壊に関する疲労寿命が 8〜26倍に向上しており，下 面増厚工法の補強効果に及ぼす増厚材料の種類や増厚部 の厚さの影響が確認できた.

(3) RC 梁の静的載荷試験および度労試験の結果から, 無 補強試験体の静的耐荷力の $40 \%$ に相当寸る換算荷重 $118 \mathrm{kN}$ の等価繰返し回数より算定したせん断耐荷力 $P_{\mathrm{sc}}$, は静的せん断而荷力実験值と同程度であった。このこと から， RC 梁の疲労試験は下面増厚工法の補強効果を評 価する試験方法として適用可能であると考えられる.

(4) RC 床版の輪荷重走行試験の結果, 昭和 39 年の鋼道 路橋設計示方書に基づいて設計された $\mathrm{RC}$ 床版は，下面 増厚補強によって, 平成 8 年の道路橋示方書に基づいて 設計された床版と同等程度まで疲労耐久性が向上した。

(5) RC 床版の輪荷重走行試験から得られた等価繰返し回 数を用いて算定した押抜きせん断耐荷力 $P_{\mathrm{sc}}{ }^{\prime}$ 'は, 下面増 厚後の押抜きせん断耐荷力計算値 $P_{s x}$ に対し, 同等以上 の耐荷力となった．このことから，下面増厚工法により 補強された床版は, 補強筋と増厚により増加寸る押抜き せん断耐荷力 $P_{s x}$ に相当する疲労耐久性を有するものと 考えられる.

(6) 増厚断面の増加によるせん断而荷力の向上分の等価 繰返し回数の向上が， $\mathrm{RC}$ 梁の疲労試験と $\mathrm{RC}$ 床版の輪 荷重走行試験の両方の試験方法で確認された. このこと から，RC 梁試験体を用いた定点載荷試験によって補強 効果を確認する手法で下面増厚床版の疲労耐久性を簡易 に照査することが可能であると考えられる. 


\section{6. おわりに}

本研究によって, 下面増厚工法の補強効果と疲労耐久 性の性能評価手法が提案できた。しかし，今回の実験は， データ数も少なく，かつ，補強前における既設 $\mathrm{RC}$ 床版 の疲労損傷状況を再現していないため，今後は，さらに 補強前の既設 RC 床版の疲労損傷を再現した試験を実施 するとともに，実橋において下面増厚が施工された RC 床版の追跡調査を実施して，より現実的な補強効果の評 価手法を確立する必要があると認識している.

謝辞：本研究における載荷試験の実施にあたり，(社)建 設機械化協会施工技術総合研究所の松本政徳氏と庄中憲 氏に協力頂いたことを記し，謝意を表します。

\section{参考文献}

1) 日本道路協会 : 道路橋示方書・同解説 II 鋼橋編, pp. 233-274, 2002.

2) 松井繁之 : 移動荷重を受ける道路橋 $\mathrm{RC}$ 床版の疲労強度と水
の影響について，コンクリート工学年次論文集，Vol.9，No.2， pp. 627-632, 1987.

3) 横山和昭，鹿野善則，福田一郎，須田久美子：下面増厚補強 した RC 梁の定点載荷疲労試験，コンクリート工学年次論文 集, Vol.24, No.2, pp.1567-1572, 2002.

4) 横山和昭，菅野匡，佐藤貢一，Meera Mohan：下面増厚した 道路橋床版の増厚構造の最適解, コンクリート工学年次論 文集，Vol.23，No.1，pp.1111-1116，2001.

5) 二羽淳一郎，山田一宇，横沢和夫，岡村甫 : せん断補強鉄筋 を用いない $\mathrm{RC}$ はりのせん断強度式の再評価，土木学会論文 集, No.372/V-5, pp.167-176, 1986.

6) 佐藤貢一, 小玉克己 : ポリマーセメントモルタル増厚補強し た RC はりの剥離破壊性状に関する基礎的研究，土木学会論 文集，No.746/V-61，pp.115-128，2003.

7) 松井繁之 : 橋梁の寿命予測一道路橋 RC 床版の疲労寿命予測 一, 安全工学, Vol.30, No.6, pp.432-440, 1991.

8) 土木学会 : コンクリート標準示方書[構造性能照査編], pp.117-118, 2002.

9) 川間重一，内田賢一，西川和廣 : 既設 RC 床版の階段状荷重 漸増載荷における疲労耐久性評価手法に関寸る検討，土木 学会第 55 回年次学術講演会, CS-257, pp.514-515, 2000.

10) 石井孝男 : 疲労寿命を考慮した鋼橋 RC 床版の設計法と維 持管理に関する研究，博士学位論文，1994.

(2005. 9.28 受付)

\title{
EXPERIMENTAL STUDY ON FATIGUE DURABILITY AND STRENGTHNING EFFECT OF BOTTOM THICKNESS INCREASING METHOD FOR RC SLABS
}

\author{
Kazuaki YOKOYAMA, Kouichi SATOH and Shinichi HINO
}

The bottom thickness increasing method is a rehabilitation work for RC slabs of highway bridges that places reinforcing bar under the existing slabs and sprayed mortar. Expressway bridges can be kept opening even during this rehabilitation work, so that this method has been applied for the bridge slab under heavy traffic condition. This rehabilitation method improves mainly the flexural strength and the shear strength of existing slabs. In order to assess the strengthening effects of this rehabilitation method for RC slabs, this study carried out the fatigue tests of RC beam specimens and the wheel running fatigue tests of real scale slab specimens with this rehabilitation work. As the results of the tests, it was clarified that the fatigue test of RC beam specimen was useful for the assessment of strengthening effects of the rehabilitation method as well as the wheel running fatigue test. As the result of these fatigue tests, it was found that the fatigue durability of RC slab was improved by the bottom thickness increasing work. 